\title{
Oral health habits, prevalence of dental caries and dental erosion in adolescents
}

\author{
Hábitos de higiene oral, prevalência de cárie e erosão dentária em adolescentes
}

Fernanda Clotilde Mariz da COSTA'

Liege Helena Freitas FERNANDES'

Eline Freitas de Farias MOURA ${ }^{1}$

Yêska Paola Costa AGUIAR ${ }^{1}$

Fábio Gomes dos SANTOS 1

Alessandro Leite CAVALCANTI1

\section{ABSTRACT}

\section{Objective}

To assess oral hygiene habits, and prevalence of dental caries and erosion in adolescents of Campina Grande, Paraiba, Brazil.

\section{Methods}

Cross-sectional study with random cluster sampling involving 201 15-year-old schoolchildren. Oral health habits were obtained through questionnaire, and socioeconomic data, by means of interviews. The DMFT index was adopted to determine the prevalence of caries and that proposed by O'Sullivan, to assess dental erosion. Data were analyzed using the Statistical Package for Social Sciences (SPSS) version 18. A 5\% significance level was adopted.

\section{Results}

All subjects reported using toothbrush and toothpaste, 50.7\% reported dental flossing, and association was found between sex and use of mouthwash $(p<0.05)$. Regarding dental caries, the mean DMFT was 3.67 and $51.7 \%$ had DMFT lower than or equal to 3. For dental erosion, $18.4 \%$ of the sample had erosive lesions, predominantly enamel lesions (92\%).

\section{Conclusion}

The use of dental floss was low and adolescents revealed unsatisfactory index. The DMF-T value was moderate and lower than that reported for the Brazilian age group. The prevalence of dental erosion was high, with predominance of enamel lesions.

Indexing terms: Dental caries. Oral hygiene. Tooth erosion.

\section{RESUMO}

Objetivo

Avaliar os hábitos de higiene oral, assim como a prevalência de cárie e erosão dentária em adolescentes em Campina Grande, Paraíba.

\section{Métodos}

Estudo transversal, com amostragem probabilística por conglomerado, envolvendo 201 escolares de 15 anos. Os hábitos de higiene oral foram obtidos por meio de questionário, e os dados socioeconômicos por entrevista. Adotou-se o índice CPO-D (Cariados, Perdidos e Obturados) para determinação da prevalência de cárie e o proposto por O'Sullivan, para avaliação da erosão dentária. Os dados foram analisados por meio do Statistical Package for the Social Sciences (SPSS) versão 18. Adotou-se um nível de significância de 5\%.

\section{Resultados}

Todos os adolescentes relataram o uso de escova dental e dentifrício, 50,7\% reportaram o uso do fio dental, sendo verificada associação entre o sexo e uso de enxaguatório bucal $(p<0,05)$. Em relação à cárie, o CPO-D médio foi de 3,67 e 51,7\% possuíam CPO-D inferior ou igual a 3 . No tocante à erosão dentária 18,4\% da amostra apresentava lesão erosiva, predominando lesões em esmalte (92\%).

\section{Conclusão}

O uso do fio dental foi baixo e os adolescentes revelaram possuir índice insatisfatório. O CPO-D foi moderado e abaixo do relatado para a faixa etária brasileira. A prevalência de erosão dentária foi elevada, com lesões predominantes em esmalte.

Termos de indexação: Cárie dentária. Higiene bucal. Erosão dentária.

\footnotetext{
${ }^{1}$ Universidade Estadual da Paraíba, Centro de Ciências Biológicas e da Saúde, Departamento de Odontologia. Rua Baraúnas, 351, Universitário, 58429 500, Campina Grande, PB, Brasil. Correspondência para / Correspondence to: FCM COSTA. E-mail: < fernandacosta3@hotmail.com>.
} 


\section{INTRODUCTION}

Factors considered extra-biological, such as economic level, behaviors and self-care have been pointed out as being factors that lead to increasing prevalence of oral pathologies in adolescents ${ }^{1}$. Dental caries is among the most frequent oral pathologies in adolescents ${ }^{2-3}$.

The last national oral health survey (SB BRASIL 2010) showed a mean DMF-T of 4.25 in adolescents from 15 to 19 years of age, but in the northeastern regions, this index rises to 4,53, and in João Pessoa, capital of the State of Paraíba, the DMF-T rises to $6.15^{2}$. These differences demonstrate regional inequalities, so that the representativity of distribution of the disease in geographical macro-regions may underestimate or mask some of the regional or local problems ${ }^{3}$.

At present, there is a variety of instruments that help to control dental biofilm and in turn, to prevent oral diseases through habits in the home, such as toothbrushing and the use of dental floss that play an important role in removing biofilm'.

In Brazil, a decline in caries disease was verified in the first decade of the 21st Century². Studies began to be directed towards other areas to monitor the trends in the population related to oral health diseases, among them, the growing prevalence of dental erosion in children and adolescents, with the main consequence of wear on the tooth surface ${ }^{4-5}$. This is of idiopathic origin or is caused by a known source of acid ${ }^{6}$, with individual factors and lifestyle having great relevance in its development ${ }^{7}$. Although studies on the prevalence of tooth erosion have been conducted in Brazil|8-11 studies involving adolescents in the Brazilian Northeast are still rare ${ }^{7}$. In view of the foregoing, the aim of this study was to evaluate the oral hygiene habits and the prevalence of dental caries and erosion in adolescents.

\section{METHODS}

\section{Ethical aspects}

This study was submitted to and approved by the Research Ethics of UEPB (Protocol 03263612.4/0000.5187).

\section{Population and sample}

The sample was composed of 201 schoolchildren 15 years of age, of both sexes, regularly enrolled in the day shift at 20 schools of the state public teaching network, localized in the urban zone of the City of Campina Grande,
PB, Brazil. The sample was of the random cluster sampling type in a stratum (group in a classroom). To participate in the study, the children's parents or guardians had to sign a Term of Free and Informed Consent (TFIC).

The following exclusion criteria were adopted: those wearing a fixed orthodontic appliance and/or with tooth enamel defects (enamel hypoplasia, dental fluorosis, and amelogenesis imperfecta) $)^{12}$.

\section{Training and calibration process}

Calibration for dental caries was developed in two stages (theoretical and practical). At the theoretical stage, the examiners were given information about the DMF-T criteria by a gold standard examiner. Afterwards, color images of the conditions to be observed were projected, and the researcher/examiner was given one minute to diagnose the lesion.

At the practical stage, the researchers performed a clinical exam in 10 randomly selected adolescents, so that each volunteer was examined by both evaluators. The results obtained were compared with the gold standard. When there was disagreement between the evaluators, these results were analyzed and reviewed. After a period of 10 days, the same volunteers were re-evaluated. On this occasion, matrices were mounted for comparing the diagnoses, and the Cohen Kappa test was performed ${ }^{13}$. The Kappa inter- and intra-examiner values obtained were 0.673 and 0.729 , respectively.

Calibration for dental erosion also consisted of two stages. At the theoretical stage, the researchers learned about the index proposed by O'Sullivan ${ }^{6}$, followed by a diagnostic test by means of projected images. At the second stage, the examiners performed clinical exams for diagnosis, followed by the reference examiner. Twenty individuals were examined, and exams were repeated until the examiners knew the criteria well. However, it was not possible to perform clinical observation of all the grades suggested by the O'Sullivan ${ }^{6}$ index, which involved the use of intra-oral color photographic images ${ }^{8-10}$ for discussing the clinical aspects of each grade and mounting matrices for comparison of the diagnoses and performing the Cohen kappa test ${ }^{13}$. The Kappa inter and intra-examiner values obtained were 0.74 and 0.82 , respectively.

\section{Data collection}

Two calibrated dentists performed the data collection, and the information was recorded by four duly trained assistants (scientific initiation students).

The sociodemographic information (sex, race and 
family income) and those referring to hygiene habits (use of toothbrush, toothpaste, dental floss, mouthwash and tongue cleaner) were collected by means of a questionnaire.

The dental exam was performed on the school premises, in a reserved room, under standardize artificial lighting ${ }^{9,14}$ coupled to the head of the researchers $^{7}$ (Petzl Zoom head lamp, Petzl America, Clearfield, UT, USA). The subjects were seated on a chair, and the examiner stood behind or in front of the chair. The examiners wore Individual Protective Equipment - IPEs.

Before the clinical exam, supervised toothbrushing was performed. The dental condition was evaluated by means of the DMF-T index, with the use of an oral mirror No.3 (Trinity, Campo Mourão, PR, Brazil) and WHO probe (Trinity, Campo Mourao, PR, Brazil) ${ }^{15}$. The DMF-T variable was dichotomized into $\leq 3$ e $>3$, in view of the World Health Organization and International Dental Federation (WHO/IDF) goal for the year $2000^{16}$.

Dental erosion was evaluated according to the index proposed by O'Sullivan ${ }^{6}$ adapted for use in the four maxillary incisors ${ }^{17}$ and maxillary and mandibular first molars 9 ,12. The choice of this index was because it included information about the severity, location and area affected by the condition, in addition to being proposed for performing the measurement of dental erosion in children and adolescents.

\section{Data analysis}

The findings were saved in a data base with the resources of the Statistical Package for the Social Sciences (SPSS), version 18.0. For data analysis, the descriptive and analytical statistical techniques were used. In the bivariate analyses the Pearson Chi-square and Exact Fisher tests were used. The level of significance considered was $5 \%$.

\section{RESULTS}

With respect to the sociodemographic characteristics, the authors verified the predominance of mulatto $(55.7 \%)$, followed by white $(21.9 \%)$, Oriental $(11.5 \%)$ and black (10.9\%) persons. Relative to family income, the majority (46.8\%) reported an income higher than or equal to two minimum wages ${ }^{18}$, while $42.8 \%$ informed a family income lower than two minimum wages. Approximately $10.4 \%$ did not know their family income. Relative to sex, predominance of the female sex was verified $(62.2 \%)$

All the adolescents reported using a toothbrush and toothpaste; however, only half the sample (50.7\%), used dental floss, so that association was verified between the use of oral mouthwash and sex (Table 1).

Table 1. Distribution of schoolchildren according to use of dental floss, tongue cleaner and mouth wash, according to sex. Campina Grande (PB), 2012.

\begin{tabular}{|c|c|c|c|c|c|c|c|c|}
\hline \multirow[t]{3}{*}{ Variable } & \multicolumn{4}{|c|}{ Sex } & & & \multirow[t]{3}{*}{$\mathrm{p}$-Value } & \multirow[t]{3}{*}{ PR CI 95\% } \\
\hline & \multicolumn{2}{|c|}{ Male } & \multicolumn{2}{|c|}{ Female } & \multicolumn{2}{|c|}{ Total } & & \\
\hline & $\mathrm{n}$ & $\%$ & $n$ & $\%$ & $\mathrm{n}$ & $\%$ & & \\
\hline \multicolumn{9}{|c|}{ Dental Floss } \\
\hline Yes & 39 & 51.3 & 63 & 50.4 & 102 & 50.7 & 0.016 & 1.03 \\
\hline No & 37 & 48.7 & 62 & 49.6 & 99 & 49.3 & & $(0.586-1.835)$ \\
\hline \multicolumn{9}{|c|}{ Tongue Cleaner } \\
\hline Yes & 5 & 6.6 & 14 & 11.2 & 19 & 9.5 & 1.179 & 0.55 \\
\hline No & 71 & 93.4 & 111 & 88.8 & 182 & 90.5 & & $(1.93-1.618)$ \\
\hline \multicolumn{9}{|c|}{ Mouth wash } \\
\hline Yes & 26 & 34.2 & 42 & 33.6 & 68 & 33.8 & 0.008 & 1.028 \\
\hline No & 50 & 65.8 & 83 & 66.4 & 133 & 66.2 & & $(0.563-1.876)$ \\
\hline
\end{tabular}

The mean DMF-T found for the sample was 3.67 ( \pm 3.31); median 3.0; minimum 0 , and maximum 15. Of the individuals, $22.9 \%$ had a DMF-T equal to zero. Approximately half of the schoolchildren $(51.7 \%$, $n=104$ ) presented a DMF-T equal to or lower than 3. With respect to the DMF-T and occurrence of dental erosion, no statistical significance was found; whereas, in relation to the use of oral hygiene instruments, association was observed between the use of a tongue cleaner and the DMF-T (Tables 2 and 3).

Relative do dental erosion, $18.4 \%$ (37) of the adolescents presented some lesions (Table 3 ). As regards the characteristics of the erosive lesions, the majority were characterized by the satin-like of the enamel, presenting 
no loss of contour (69.7\%), localized on the vestibular surface $(58.9 \%)$ and with less than half of the surface affected (59.9\%). The authors observed a clear prevalence of lesions restricted to tooth enamel (92\%) (Table 4).

Table 2. Distribution of schoolchildren according to DMF-T; sex; use of dental floss, tongue cleaner and mouthwash. Campina Grande (PB), 2012

\begin{tabular}{|c|c|c|c|c|}
\hline \multirow[t]{2}{*}{ Variable } & \multicolumn{2}{|c|}{ DMF-T } & \multirow{2}{*}{$p$-Value } & \multirow[t]{2}{*}{ PR CI 95\% } \\
\hline & $\leq 3$ & $>3$ & & \\
\hline \multicolumn{5}{|l|}{ Sex } \\
\hline Female & 61 & 64 & \multirow{2}{*}{$\begin{array}{c}1.145 \\
(0.771-2.426)\end{array}$} & \multirow[t]{2}{*}{1.367} \\
\hline Male & 43 & 33 & & \\
\hline \multicolumn{5}{|c|}{ Dental Floss } \\
\hline Yes & 47 & 55 & \multirow{2}{*}{$\begin{array}{c}2.660 \\
(0.361-1.099)\end{array}$} & \multirow[t]{2}{*}{0.630} \\
\hline No & 57 & 42 & & \\
\hline \multicolumn{5}{|l|}{$\begin{array}{l}\text { Tongue } \\
\text { Cleaner }\end{array}$} \\
\hline Yes & 10 & 9 & \multirow{2}{*}{$\begin{array}{c}0.007 \\
(0.404-2.680)\end{array}$} & \multirow[t]{2}{*}{1.040} \\
\hline No & 94 & 88 & & \\
\hline \multicolumn{5}{|c|}{ Mouthwash } \\
\hline Yes & 36 & 32 & \multirow{2}{*}{$\begin{array}{c}0.059 \\
(0.599-1.930)\end{array}$} & \multirow[t]{2}{*}{1.075} \\
\hline No & 68 & 65 & & \\
\hline
\end{tabular}

Table 3. Distribution of schoolchildren according to presence of erosion and DMF-T. Campina Grande (PB), 2012.

\begin{tabular}{|c|c|c|c|c|c|c|}
\hline \multirow[t]{3}{*}{ Variable } & \multicolumn{4}{|c|}{ DMF-T } & \multirow[t]{3}{*}{$p$-Value* } & \multirow[t]{3}{*}{ PR Cl $95 \%$} \\
\hline & \multicolumn{2}{|c|}{$\leq 3$} & \multicolumn{2}{|c|}{$\geq 4$} & & \\
\hline & $\mathrm{n}$ & $\%$ & $\mathrm{n}$ & $\%$ & & \\
\hline \multicolumn{7}{|l|}{$\begin{array}{l}\text { Dental } \\
\text { erosion }\end{array}$} \\
\hline Yes & 21 & 10.4 & 16 & 8 & 0.057 & $(0.52-2.28)$ \\
\hline No & 72 & 35.8 & 60 & 29.9 & & \\
\hline
\end{tabular}

Table 4. Characteristic of dental erosion in rate of affected teeth. Campina Grande (PB), 2012.

\begin{tabular}{|c|c|c|}
\hline Characteristics of Dental erosion & $\mathrm{n}$ & $\%$ \\
\hline \multicolumn{3}{|l|}{ Severity } \\
\hline $\begin{array}{l}\text { Satin-like appearance of enamel (without loss of } \\
\text { contour) }\end{array}$ & 78 & 69.7 \\
\hline Loss of enamel (with loss of contour) & 25 & 22.3 \\
\hline Loss of enamel with dentin exposure (ADJ visible) & 9 & 8 \\
\hline \multicolumn{3}{|l|}{ Localization } \\
\hline Vestibular only & 66 & 58.9 \\
\hline Palatine or lingual only & 24 & 21.5 \\
\hline Occlusal or incisal only & 6 & 5.3 \\
\hline Multiple surfaces & 16 & 14.3 \\
\hline \multicolumn{3}{|l|}{ Area affected } \\
\hline Over half of the surface & 45 & 40.1 \\
\hline Less than half of the surface & 67 & 59.9 \\
\hline Total of teeth with erosion & 112 & 18.4 \\
\hline
\end{tabular}

\section{DISCUSSION}

The moderate to high prevalence of dental caries continues to be a reality worldwide ${ }^{19}$. The frequency of brushing; use of dental and regular visits to the dentists are important determinants of oral health ${ }^{18}$.

Relative to the socioeconomic characteristics referring to race, the majority of the participants declared they were mulattos; this could be explained since the majority of the Northeastern population affirm being mulatto $^{20}$. According to Carvalho ${ }^{21}$, the increase in the number of those declaring they were mulatto in the Brazilian census is justified by the "migration" of white and black people to the category mulatto, and not by the occurrence of the racial miscegenation process.

In this study, the majority of the adolescents reported an income equal to or higher than two minimum wages. The female sex accounted for the majority of the sample. However, the oral hygiene habits reported were better in the male sex, corroborating the findings of a previous study. According to Calderon and Mallory ${ }^{22}$, the socioeconomic and behavioral factors have an influence on the development of poor oral hygiene habits, and this in turn influences the development and both the prevalence and incidence of dental caries disease.

Control of dental biofilm involves different mechanisms, such as the use of dental floss, toothbrushing and use of oral mouthwashes, among others ${ }^{23}$. All the adolescents reported that they brushed their teeth at least once a day, and half of the sample mentioned the use of dental floss. The use of these means by schoolchildren could be a regular means of removing biofilm, helping to contain carious and periodontal infections, seeing that they are directly related to deficient oral hygiene ${ }^{2}$. There was a low level of use of the tongue cleaner, and association was found between the use of this hygiene instrument and DMF-T.

With respect to the DMF-T index, the WHO recommends that at twelve years of age, this should be equal to or lower than $3.0^{19}$. In the Brazilian case, this goal was observed by SB Brasil $2003^{24}$ when the index attained 2.78, presenting a decline to 2.07 in 2010 (SB Brasil 2010). ${ }^{3}$ Nevertheless, because it is a per capita value, it does not reflect the reality of all the regions ${ }^{4}$, considering that in the Northeast the goal was only attained in 2010 $(D M F-T=2.63)^{3}$. In this study we identified a mean DMF-T value of 3.67 , with a median of 3.0 for the sample of schoolchildren, this result being lower than that found in 
the Brazilian Northeast for adolescents from 15 to 19 years of age $(4,53)^{3}$.

Approximately half of the adolescents presented a DMF-T equal to or lower than 3, corroborating the findings of Cangussu et al. ${ }^{25}$ and Rocalli et al. ${ }^{26}$. The reduction in the dental caries indicators in Brazil is clear, and has been demonstrated in population-based studies ${ }^{25}$. This important trend towards decline in caries is linked to the spread of access to services, greater perception of oral health diseases and exposure to fluoride, considered the main factor for local control ${ }^{3,26}$.

Relative to erosive lesions, $18.4 \%$ of the sample presented lesion in at least one tooth, similar to the findings of Gurgel et al. ${ }^{8}$ and Mangueira et al. ${ }^{10}$. Over the course of the last decade there has been a significant increase in the prevalence and severity of erosive dental wear, particularly

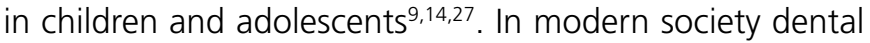
erosion is known to be an important cause of loss of dental structure $^{9,14,23}$

Relative to the severity of erosive lesions, the majority of the participants presented lesion only in enamel, corroborating the findings described by Huew et al. ${ }^{27}$ and Mulic et al. ${ }^{28}$. With reference to localization, the vestibular surface was the most affected, according to Dukic et al. ${ }^{29}$; a fact due to the close contact with potentially erosive beverages (sodas and citric juices).

The smooth silky appearance with absence of periquimacies and intact enamel along the gingival margins are some of the typical signs of enamel erosion on these surfaces $^{27-28}$. If left untreated, erosion may cause sensitivity, discoloration and change in the shape of teeth, resulting in esthetic and functional compromise ${ }^{25}$.

There was no significance in the concomitant manifestation of erosive lesions and DMF-T. This result may be explained by the fact that erosion is the chemical dissolution of dental enamel cause by acids without bacterial involvement ${ }^{25}$, thus, in principle, it has etiologic factors that differ from those of dental caries. These pathologies do however, have one and the same risk factor - high consumption of foods rich in sugar, which in general have high erosive potential ${ }^{30}$.

\section{REFERENCES}

1. Claydon NC. Current concepts in toothbrushing and interdental cleaning. Periodontol 2000. 2008;48:10-22. doi: 10.1111/j.1600-0757.2008.00273.x

2. Brasil. Ministério da Saúde. Secretaria de Atenção à Saúde. Secretaria de Vigilância em Saúde. SB Brasil 2010: Pesquisa
Some of the methodological limitations of the present study must be observed; among them the fact that the study has a cross-sectional design in which the outcome corresponds to a single moment in time. Another aspect to be pointed out was the initial resistance of some of the schools or teachers to receiving the researchers, because they did not understand the importance of studies for the planning of actions in oral health.

\section{CONCLUSION}

The use of dental floss and other means of oral hygiene were unsatisfactory. The mean DMF-T found was 3.67, median 3.0, minimum 0 and maximum of 15 was considered moderate and below the value reported for the Brazilian age group, but varying considerably. The prevalence of dental erosion with lesions predominantly in enamel was found among the adolescents.

\section{Acknowledgements}

The authors thank the adolescents who participated in the study, directors of schools and the local authorities.

\section{Collaborators}

FCM COSTA, with acquisition, analysis and interpretation of data. Drafting the article associated to her completion of course work. LHF FERNANDES, conception about this paper, acquisition of data, also revising it critically for important intellectual contente. EFF MOURA, with acquisition of data and data tabulation. Also contributed of revising it critically this paper. YPC AGUIAR and FG SANTOS, acquisition of data, co-interpretation of data and contributions to conception and desing this paper. Resising and with final approval of the version to be published. AL CAVALCANTI, co-interpretation of data and contributions to conception and desing this paper. Revising it critically for important intellectual content. Resising and with final approval of the version to be published.

Nacional de Saúde Bucal: resultados principais. Brasília: Ministério da Saúde; 2012.

3. Fonseca TGG, Lopes MCL, Vieira JMR, Parente RCP, Rebelo MAB Caries experience in adolescents from a metropolitan region of the Brazilian Amazon. Rev Odonto Ciênc. 2009;24(4):349-53.

4. Auad SM, Waterhouse PJ, Nunn JH, Moynihan PJ. Dental caries and its association with sociodemographics, erosion, and 
diet in schoolchildren from southeast Brazil. Pediatr Dent. 2009;31(3):229-35.

5. Aguiar YPC, Santos FG, Moura EFF, Costa FCMC, Auad SM, Paiva SM, et al. Association between dental erosion and diet in Brazilian adolescents aged from 15 to 19: a population-based study. Sci World J. 2014;1-7. doi: 10.1155/2014/818167

6. O'Sullivan EA. A new index for the measurement of erosion in children. Eur J Paediatr Dent. 2000;1(2):69-74.

7. Gurgel CV, Rios D, Oliveira TM, Tessarolli V, Carvalho FP, Machado MAAM. Risk factors for dental erosion in a group of 12- and16-yearold Brazilian schoolchildren. Int J Paediatr Dent. 2011;21(1):50-57. doi: 10.1111/j.1365-263X.2010.01090.x

8. Auad SM, Waterhouse PJ, Nunn JH, Steen N, Moynihan PJ. Dental erosion amongst 13- and 14-year-old Brazilian schoolchildren. Int Dent J. 2007;57(3):161-67. doi: 10.1111/j.1875-595X.2007. tb00119.x

9. Correr GM, Alonso RCB, Correa MA, Campos EA, Barrato-Filho F, Puppin-Rontani RM. Influence of diet and salivary characteristics on the prevence of dental erosion among 12-year-old schoolchildren. J Dent Child. 2009;76(3):181-87.

10. Mangueira DFB, Alves DN, Sampaio FC, Oliveira AFB. Prevalência e fatores associados à erosão dentária em escolares de João Pessoa. Ciências Saúde. 2009;20(1):29-36.

11. Vargas-Ferreira F, Praetzel J R, Ardenghi TM. Prevalence of tooth erosion and associated factors in 11-14-year-old Brazilian schoolchildren. J Public Health Dent. 2011;71(1):6-12. doi: 10.1111/j.1752-7325.2010.00194.x

12. Vargas-Ferreira F, Piovesan C, Praetzel JR, Mendes FM, Allison PJ, Ardenghi TM. Tooth erosion with low severity does not impact child oral health-related quality of life. Caries Res. 2010;44(6):531-9. doi: 10.1159/000321447

13. Cohen J. A coefficient of agreement for nominal scales. Educ Psychol Meas. 1960;20(1):37-46.

14. Arnadottir IB, Holbrook WP, Eggertsson $H$, Gudmundsdottir $H$, Jonsson SH, Gudlaugsson JO, et al. Prevalence of dental erosion in children: a national survey. Community Dent Oral Epidemiol. 2010 Dec;38(6):521-6. doi: 10.1111/j.1600-0528.2010.00559.x

15. World Health Organization. Oral health surveys: basic methods $4^{\text {th }}$ ed. Geneva: WHO; 1997

16. Fédèration Dentaire Internationale. Global goals for oral health in the year 2000. Int Dent J. 1982 Mar;32(1):74-7.

17. Peres KG, Armênio MF, Peres MA, Traebert j, De Lacerda JT. Dental erosion in 12-yers-old schoolchildren: a cross sectional study in southern Brasil. Int J Paediatr Dent. 2005;15(4):249-55.

18. Brasil, Presidente (2012-: D.V.Rousseff). Mensagem ao Congresso Nacional, 2011: $2^{a}$ Sessão Legislativa Ordinária da 54 Legislatura. Brasília: Presidência da República; 2012.
19. Skinner et al. Dental caries in 14-and 15-year-olds in New South Wales, Australia. BMC Public Health. 2013;13:1060. doi: 10.1186/1471-2458-13-1060

20. IBGE. Ministério do Planejamento, Orçamento e Gestão. Pesquisa nacional de amostra domiciliar. Brasília: IBGE; 2012.

21. De Carvalho JAM, Wood CH, Andrade FCD. Notas acerca das categorias de cor dos censos e sobre a classificação subjetiva de cor no Brasil: 1980/90. Rev Bras Est Pop. 2013;20(1):29-42.

22. Calderon SJ, Mallory C. A systematic review of oral health behavior research in American adolescents. J Sch Nurs. 2014;30(6):396403. doi: $10.1177 / 1059840514544034$

23. Huysmans MCDNJM, Chew HP, Ellwood RP. Clinical Studies of Dental Erosion and Erosive Wear. Caries Res. 2011;45 Suppl 1:60-8. doi: 10.1159/000325947

24. Brasil. Ministério da Saúde. Secretaria de Atenção à Saúde. Departamento de Atenção Básica. Projeto SB Brasil 2003: condições de saúde bucal da população brasileira 2002-2003: resultados principais Brasília: Ministério da Saúde; 2005.

25. Cangussu MCT, Lopes LS. Epidemiologia da cárie dentária no estado da Bahia de 1986 a 2012. Rev Baiana Saúde Pub. 2012;36(3):640-50.

26. Roncalli AG. Projeto SB Brasil 2010. Pesquisa Nacional de Saúde Bucal revela importante redução da cárie dentária no país. Cad Saúde Pública. 2011;27(1):4-5. doi: 10.1590/S0102$311 \times 2011000100001$

27. Huew R, Waterhouse PJ, Moynihan PJ, Kometa S, Maguire A. Dental erosion and its association with diet in Libyan schoolchildren. Eur Arch Paediatr Dent. 2011;12(5):234-40.

28. Mulic A, Tveit AB, Songe $D$, Sivertsen $H$, Skaare AB. Dental erosive wear and salivary flow rate in physically active young adults. BMC Oral Health. 2012;12:8. doi: 10.1186/1472-6831-12-8

29. Dukic W, Dobrijevic TT, Katunaric M, Miladorvic S, Segovic S. Erosive lesions in patients with alcoholism. J Am Dent Assoc. 2010;141(12):1452-58.

30. Huew R, Waterhouse P, Moynihan P, Kometa S, Maguire A. Caries, diet and erosion in Libyan schoolchildren. Int J Paediatr Dent. 2012 Jan;22(1):68-76. doi: 10.1111/j.1365-263X.2011.01170.x

Received on: 2/7/2016 Final version resubmitted on: 19/4/2017 Approved on: 17/5/2017 